\title{
A simple 'paper smear' method for dry collection, transport and storage of cervical cytological specimens for rapid screening of HPV infection by PCR
}

\author{
U. KAILASH, S. HEDAU, V. GOPALKRISHNA, S. KATIYAR and B. C. DAS
}

Division of Molecular Oncology, Institute of Cytology and Preventive Oncology (ICMR), Maulana Azad Medical College Campus, New Delhi - 110002, India

\begin{abstract}
Human papillomaviruses (HPVs) are major pathogens associated with the development of cancer of the uterine cervix, the most common malignant tumour of women worldwide. Reliable diagnosis of HPV infection, particularly the 'high-risk' types (16/18), may facilitate early identification of 'high-risk' populations for developing cervical cancer and may augment the sensitivity and specificity of primary cervical cancer screening programmes by complementing the conventional Pap test. A simple paper smear method has been developed for dry collection, transport and storage of cervical smears/scrapes at room temperature for subsequent detection of HPV DNA by PCR assay. Imprint biopsies, blood and fine-needle aspirates were also collected by this method. The cervical scrapes or other body fluids were smeared (within $0.5-1 \mathrm{~cm}$ diameter) and dried on to sterile small slides made of Whatman 3MM filter paper, and stored individually at room temperature or at $4^{\circ} \mathrm{C}$. A small piece $(2-3 \mathrm{~mm})$ of the paper smear was punched or cut out with a sterile surgical blade, boiled in an eppendorf tube containing $50 \mu \mathrm{l}$ of distilled water for $5 \mathrm{~min}$ and used directly for PCR amplification. The quality and quantity of DNA derived from paper smears and the results of PCR amplifications for HPV type 16, BRCA1 and p53 genes were identical to those obtained from the same samples following collection in $\mathrm{PBS}$, storage $\left(-70^{\circ} \mathrm{C}\right)$ and phenol-chloroform-based DNA extraction. DNA was stable in the paper smears for up to a year, whether stored at room temperature or at $4^{\circ} \mathrm{C}$. This method is simple, rapid and cost-effective, and can be effectively employed for large-scale population screening, especially for regions where the specimens are to be transported from distant places to the laboratory.
\end{abstract}

\section{Introduction}

Cancer of the uterine cervix is the most common malignant tumour in women world-wide and represents a major public health problem in India and south-east Asia. In India, c. 100000 women develop this cancer every year $[1,2]$, contributing $c .16 \%$ of the global annual incidence [3]. Human papillomaviruses (HPVs) have emerged as major pathogens associated with this disease [4-6]. Around 20 of the 100 or more different HPV types thus far identified are associated with cancers of the lower genital tract, whereas other types

Received 9 July 2001; revised version received 25 Jan. 2002; accepted 24 Feb. 2002.

Corrresponding author: Dr B. C. Das (e-mail: bcdas48@, hotmail.com). cause warts and other diseases in different epithelial organ sites $[7,8]$. Up to $98 \%$ of cervical cancers may be positive for HPV [9]. HPV infections in the general population are highly prevalent as clinically latent infections. Individuals carrying 'high-risk' HPVs (e.g., types 16 and 18) show a high rate of progression of dysplasia to invasive cancer of the cervix [5, 10-12]. Thus, reliable diagnosis of HPVs may facilitate early identification of women at increased risk of developing cervical cancer. Furthermore, the Papanicolaou smear test (Pap test), generally employed for cytomorphological diagnosis of early cervical lesions, is not fully reliable. Incorporation of HPV testing along with the Pap test may significantly augment the sensitivity and specificity of primary cervical cancer screening programmes $[13,14]$. Diagnosis of HPV relies mainly upon viral genome detection by nucleic acid hybridi- 
sation or PCR assays of cellular DNA extracted from either cervical scrapes or tumour biopsy specimens. However, these methods suffer from several technical limitations associated with collection, transport and storage of specimens. Scraped cervical cells or tumour biopsies are generally collected in cold PBS solution, transported on ice, and stored at $-70^{\circ} \mathrm{C}$ or in liquid nitrogen until further processing. The standard procedure of DNA isolation by proteinase $\mathrm{K}$ digestion and phenol-chloroform extraction is complex, expensive, hazardous, time-consuming and unsuitable for screening large numbers of specimens at a time.

This paper describes a simple 'paper smear' procedure for collecting cervical smear/scrapes or biopsy specimens on to a sterile paper slide made up of Whatman $3 \mathrm{MM}$ filter paper which can then be easily air-dried and stored at room temperature. The slides can then be easily transported from the clinic or field to the laboratory. The technique was validated with various other biological specimens. A similar procedure has been widely used for collecting dry blood spots to screen for various infectious agents [15-19] and metabolic and genetic diseases [20-22].

\section{Materials and methods}

\section{Study subjects and specimens}

Four different types of biological specimens were collected: (i) 50 cervical scrapes and (ii) 50 tumour biopsy specimens, for detection of HPV 16 DNA sequences, (iii) fine-needle aspirate cells (FNACs) from 30 women with breast carcinomas for detection of the breast cancer susceptibility gene BRCA1 (exon 2) and the p53 gene (exon 5), and (iv) peripheral venous blood from 20 normal healthy individuals for detection of the same p53 gene exon.

\section{Specimen collection, transport and storage}

Cervical scrapes and tumour biopsies were obtained from women with cervical dysplasias and carcinomas, respectively, from the Gynecology Outpatient Department and Cancer Clinic of Lok Nayak Hospital, New Delhi. Scraped cervical cells obtained by Ayer's spatula were first smeared on to a $3 \mathrm{MM}$ Whatman paper cut to the size of a small glass slide $(5 \mathrm{~cm} \times 2 \mathrm{~cm})$. Smearing was done within a $0.5-1.0 \mathrm{~cm}$ diameter in the middle of the filter-paper slide. The spatula and the rest of the scraped cell materials were transferred to a $15-\mathrm{ml}$ collection vial containing $5 \mathrm{ml}$ of PBS on ice and then stored at $-70^{\circ} \mathrm{C}$. Tumour biopsies were either imprinted or the tumour cell suspension was blotted on to the paper slide. The remaining biopsy was collected in PBS and stored at $-70^{\circ} \mathrm{C}$ for comparison. FNACs $(5-10 \mu \mathrm{l})$ from breast cancer patients and heparinised blood (5$10 \mu \mathrm{l})$ from healthy individuals were spotted as paper smears and the remaining material was processed by standard procedures. All paper smears performed in duplicate were put into individual auto-seal (ziplock) polythene bags. Half of these bags were stored at room temperature $\left(25-30^{\circ} \mathrm{C}\right)$ and the rest at $4^{\circ} \mathrm{C}$ until analysis. Cervical specimens as paper smears were also obtained in envelopes sent by post from distant parts of India. All samples were stored for at least 3-4 weeks before analysis. One set of paper smears was stored for up to 1 year at room temperature.

\section{$D N A$ extraction and PCR}

A small piece $(2-3 \mathrm{~mm})$ of the dried paper smear specimens was punched or cut out with a sterile singlecut paper-punching machine or with a new sterile scalpel blade, and transferred to a $0.5-\mathrm{ml}$ microcentifuge tube containing $50 \mu \mathrm{l}$ of distilled water. This was then boiled for $5 \mathrm{~min}$ in a microwave oven $(360 \mathrm{~W}$; Bosch). After reduction in volume to $10 \mu 1$ in a speedvac concentrator, PCR mix with Taq DNA polymerase (Perkin-Elmer Cetus, Roche, NJ, USA) and primers was added to the tube. Amplification was performed in a $30-\mu 1$ reaction mix in a DNA thermal cycler (PerkinElmer Cetus) by a protocol described previously $[9,12]$. A larger amount of DNA was also extracted from several single punched-out paper smear disks in an eppendorf tube by a non-organic method described previously [23]. DNA extraction from cervical scrapes and tumour biopsies collected in PBS and stored at $-70^{\circ} \mathrm{C}$ was performed by standard proteinase $\mathrm{K}$ digestion and phenol-chloroform methodology $[9,12,24]$.

\section{PCR amplification and amplicon detection}

Two PCR reactions, one for DNA obtained by standard procedures and another for paper smear-derived DNA, were performed simultaneously for each of the four types of biological specimens collected. Also, PCR was performed separately for the DNA of paper smear samples stored either at room temperature or at $4^{\circ} \mathrm{C}$. The primers for HPV 16, BRCA1 and p53 (see Table 1) were synthesised in an automated DNA Synthesizer (Model 381A; Applied Biosystems, Foster City, CA, USA) by phosporamidite chemistry and were purified by high-performance liquid chromatography (HPLC). After PCR, $15 \mu \mathrm{l}$ of the amplified product were run on an ethidium bromide-stained Nusieve agarose 3\% gel (FMC Bioproducts, Rockland, USA) and visualised with a UV transilluminator. Every PCR reaction included positive and negative controls. Strict laboratory precautions and control measures [25] were followed to avoid cross-contamination and carry-over in the PCR assay.

\section{Results}

The quality and quantity of DNA extracted from the dried paper smears by boiling were comparable to those obtained by standard collection and phenol- 
Table 1. Oligonucleotide primer sequences used for amplification of HPV 16 and other genes

\begin{tabular}{|c|c|c|c|c|}
\hline $\begin{array}{l}\text { Genomes/ } \\
\text { genes }\end{array}$ & $\begin{array}{l}\text { Primer } \\
\text { location }\end{array}$ & $\begin{array}{l}\text { Nucleotide } \\
\text { position }\end{array}$ & $\begin{array}{l}\text { Amplicon } \\
\text { size (bp) }\end{array}$ & Primer sequences \\
\hline \multirow[t]{2}{*}{ HPV 16} & URR & $7763-7781$ & 217 & 5'- AAG GCC AAC TAA ATG TCA C-3' \\
\hline & & $57-75$ & & 5'- CTG CTT TTA TAC TAA CCG G -3' \\
\hline \multirow[t]{2}{*}{ BRCA1 } & Exon 2 & $4557-4580$ & 258 & $\begin{array}{l}\text { 5'- GAA GTT GTC ATT TTA TAA ACC TTT - } \\
3^{\prime}\end{array}$ \\
\hline & & $4793-4814$ & & 5'- TGT CTT TTC TTC CCT AGT ATG T -3' \\
\hline \multirow[t]{2}{*}{ p53 } & Exon 5 & $13055-13074$ & 184 & 5'- TAC TCC CCT GCC CTC AAC AA -3' \\
\hline & & $13219-13238$ & & 5'- CAT CGC TAT CTG AGC AGC GC -3' \\
\hline
\end{tabular}

chloroform extractions, as estimated by ethidium bromide-stained agarose gel electrophoresis (Fig. 1). There was also no difference in the quality of DNA isolated from paper smears stored at room temperature or at $4^{\circ} \mathrm{C}$. To determine an optimal boiling time for DNA elution from paper smears, single punched-out paper disks were boiled for 2, 5, 7 or $10 \mathrm{~min}$. Microwaving for $5 \mathrm{~min}$ (actual boiling time) gave the best results in terms of PCR signal generated (data not shown).

For HPV 16, 217-bp amplicons were detected with equal frequency in cervical scrapes and tumours whether collected by paper smear or by standard procedures (Fig. 2, Table 2). Similarly, the BRCA1 and p53 gene amplifications in FNACs or in blood samples were equally successful with paper smear-derived and conventionally prepared DNA (Table 2). Paper smears $(>200)$ obtained by ordinary post, even during summer months when the temperature rose to $40-46^{\circ} \mathrm{C}$ in India, generated the same results as standard procedures.

To evaluate the stability of the paper smear specimens for DNA elution and PCR amplification, some smears were stored for 1,6 or 12 months. There was no discernible difference between DNA eluted or PCR amplifications obtained from smears stored for up to a year, whether at room temperature or at $4^{\circ} \mathrm{C}$ (Fig. 3).

For additional molecular biology experiments, it was possible to extract a larger amount of DNA from the paper smears by using multiple pieces of the paper slides dropped into a microcentrifuge tube containing $100 \mu \mathrm{l}$ of distilled water and processed for DNA extraction by a simple non-organic method. It was found that $5-7 \mu \mathrm{g}$ of DNA could be extracted ( $>90 \%$ recovery) easily from a single paper smear and the DNA was suitable for PCR amplification, restriction endonuclease digestion and cloning or sequencing (data not provided).

\section{Discussion}

This study analysed $>300$ paper smears from various clinical specimens and obtained results that were identical to those obtained by conventional methods. Collection of cytological samples on small filter-papers and their dry shipment and storage at room temperature, coupled with a simple boiling or a non-organic method of DNA extraction, solves several disadvantages and reduces biohazards associated with the
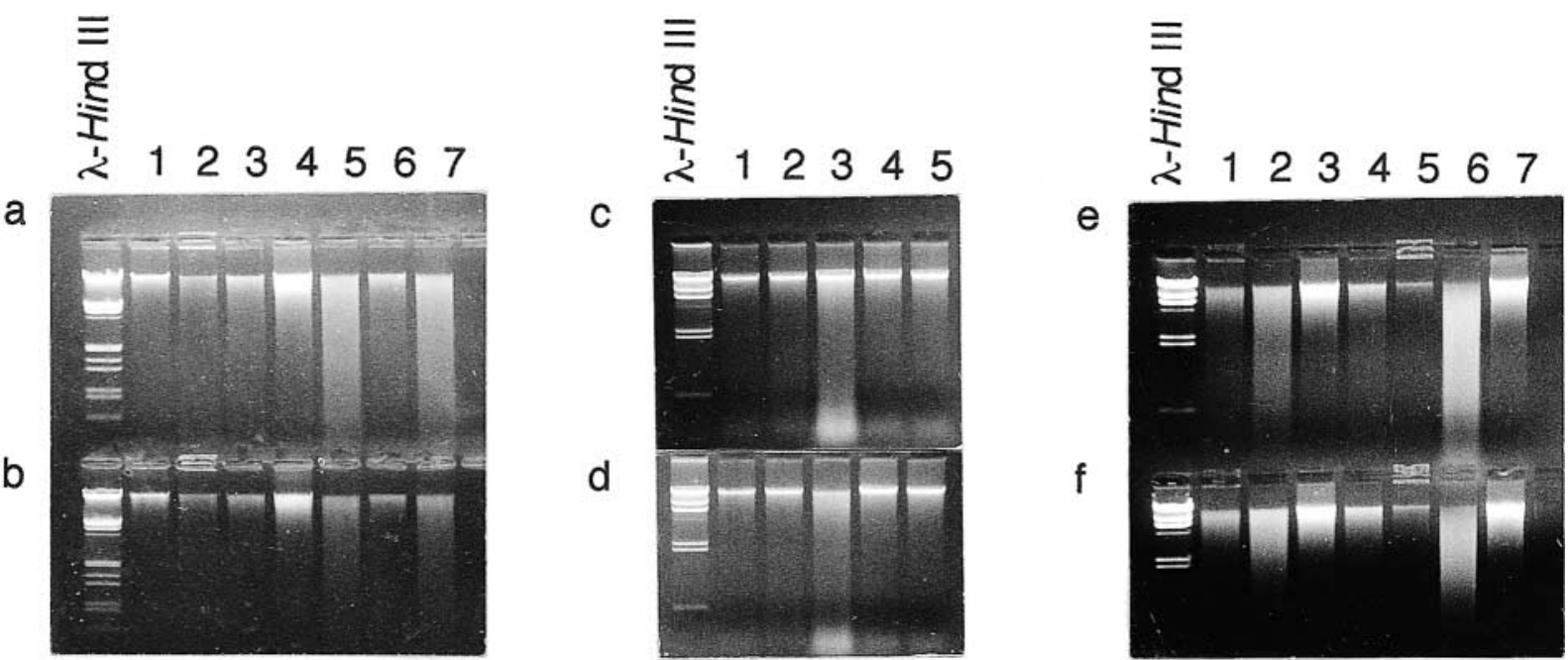

Fig. 1. Ethidium bromide-stained agarose gel electrophoresis showing quality and quantity of high mol. wt genomic DNA extracted from cervical scrapes $(\mathbf{a}, \mathbf{b})$, fine-needle aspirated breast carcinoma cells $(\mathbf{c}, \mathbf{d})$ and blood $(\mathbf{e}, \mathbf{f})$. DNA samples shown in upper panels (a, c and e) were extracted by standard phenol-chloroform methods following collection of specimens in cold PBS and storage at $-70^{\circ} \mathrm{C}$, whereas the DNA samples shown in the lower panels $(\mathbf{b}, \mathbf{d}$ and $\mathbf{f})$ were from the same samples collected on paper smears and DNA extracted by boiling. 

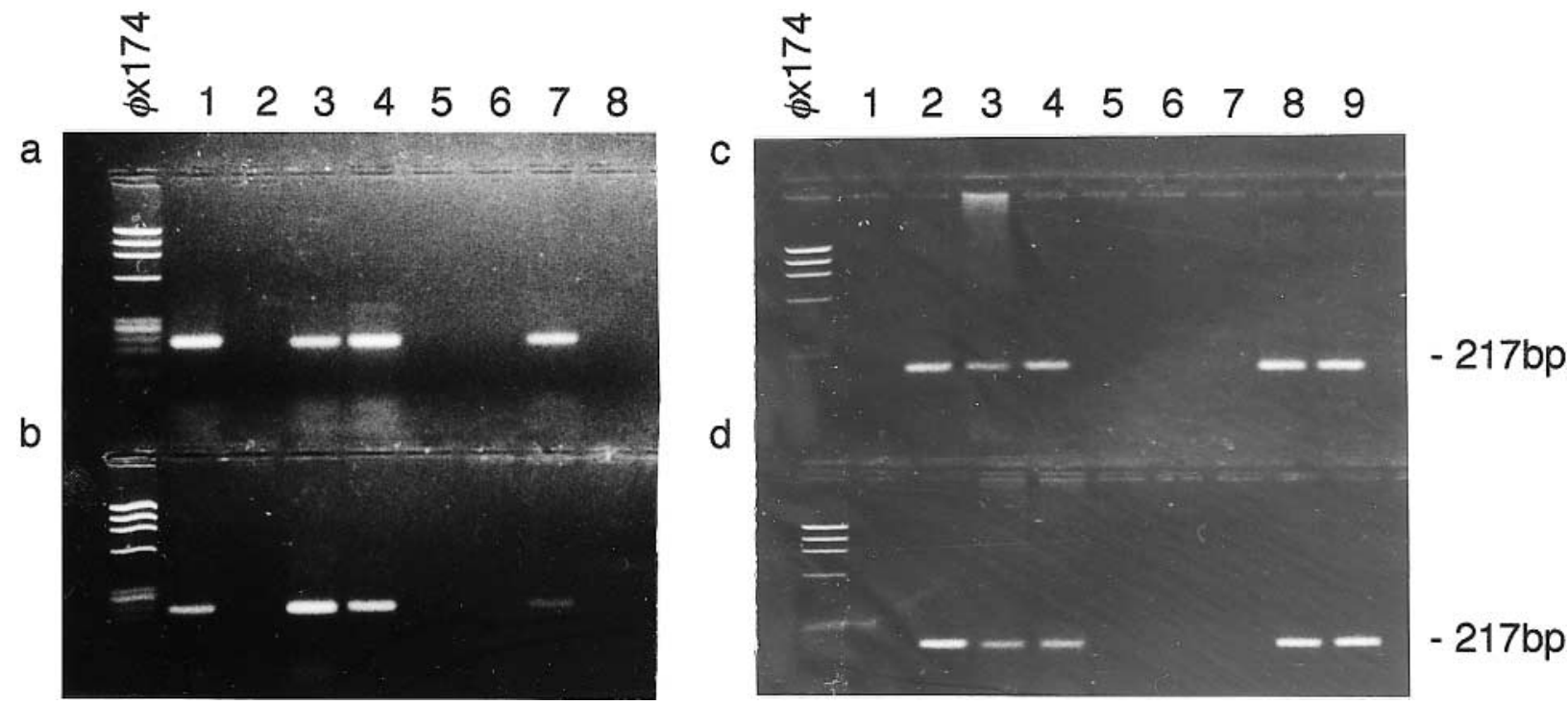

Fig. 2. PCR amplification of HPV type 16 in cervical scrapes $(\mathbf{a}, \mathbf{b})$ and cervical tumour biopsy specimens $(\mathbf{c}$, d) collected and stored by standard procedures (a, c) and by paper smear methods (b, d). Amplimers of $217 \mathrm{bp}$ are seen in lanes 3, 4 and 7 in both (a) and (b) and lanes 3, 4, 8 and 9 in (c) and (d). Lane 1 in (a) and (b) and lane $\mathbf{2}$ in (c) and (d) are positive controls. Lane 2 in (a) and (b) and lane $\mathbf{1}$ in (c) and (d) are negative controls (placental DNA).

Table 2. Quality of DNA and PCR positivity for HPV and other genes in different clinical cytological specimens collected as paper smears or by standard procedures

\begin{tabular}{|c|c|c|c|c|c|c|c|}
\hline \multirow[b]{2}{*}{ Type of specimen } & \multirow[b]{2}{*}{$\begin{array}{l}\text { Number of } \\
\text { specimens }\end{array}$} & \multirow[b]{2}{*}{$\begin{array}{l}\text { Genomes/gene } \\
\text { detected }\end{array}$} & \multirow[b]{2}{*}{$\begin{array}{l}\text { Primer } \\
\text { location }\end{array}$} & \multicolumn{4}{|c|}{ Quality* of DNA and number of PCR-positive samples } \\
\hline & & & & $\begin{array}{l}\text { Standard } \\
\text { extraction }\end{array}$ & $\begin{array}{c}\text { PCR } \\
\text { positivity }\end{array}$ & $\begin{array}{l}\text { Extraction } \\
\text { by boiling }\end{array}$ & $\begin{array}{c}\text { PCR } \\
\text { positivity }\end{array}$ \\
\hline Cervical scrape & 50 & HPV 16 & URR & $\begin{array}{c}+++ \\
50\end{array}$ & $\begin{array}{c}+++ \\
14\end{array}$ & $\begin{array}{c}+++ \\
50\end{array}$ & $\begin{array}{c}+++ \\
14\end{array}$ \\
\hline Cervical tumour & 50 & HPV 16 & URR & $\begin{array}{c}+++ \\
50\end{array}$ & $\begin{array}{c}+++ \\
39\end{array}$ & $\begin{array}{c}+++ \\
50\end{array}$ & $\begin{array}{c}+++ \\
39\end{array}$ \\
\hline $\begin{array}{l}\text { FNAC breast } \\
\text { carcinoma }\end{array}$ & 30 & BRCA 1 & Exon 2 & +++ & +++ & +++ & +++ \\
\hline Blood & 20 & $\mathrm{p} 53$ & Exon 5 & $\begin{array}{c}30 \\
+++ \\
20\end{array}$ & $\begin{array}{c}30 \\
+++ \\
20\end{array}$ & $\begin{array}{c}30 \\
+++ \\
20\end{array}$ & $\begin{array}{c}30 \\
+++ \\
20\end{array}$ \\
\hline
\end{tabular}

$*_{+}++$indicates good quality DNA and PCR signal.

a

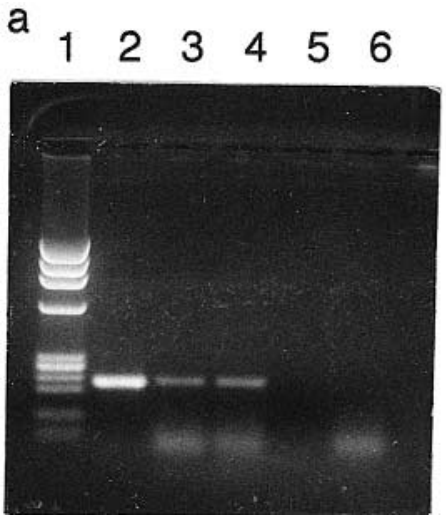

b
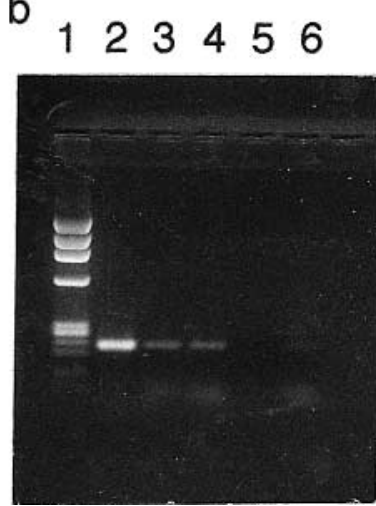

$-217 b p$

Fig. 3. PCR amplification of HPV 16 in cervical scrapes collected as paper smears and stored at room temperature for (a) 6 months and (b) 1 year. Lanes: 1, HaeIII-digested $\phi$ X174 DNA mol. wt markers; 2, positive control; 3 and 4, HPV-positive samples; 5 and 6, negative samples.

conventional handling of biological specimens and DNA extraction for large-scale population or epidemiological studies. The dried paper smear method is simple, rapid, safe and most convenient for collection, storage and transport of cervical scrapes/smears and biopsies and allows detection of HPV DNA or other gene sequences by PCR. The infectious hazard will also be reduced if pathogens present in clinical material do not survive drying and long-term storage. A larger amount of genomic DNA can be isolated from such 
dried paper smears if necessary, by using an extraction method with higher amounts of proteinase $\mathrm{K}$ at higher temperature $\left(60-65^{\circ} \mathrm{C}\right)$, after which the enzyme is auto-inactivated and autolysed [23, 26]. This method is cost-effective compared with commercial extraction kits and is also rapid, as the entire procedure takes $<3 \mathrm{~h}$. It is performed in a single microcentrifuge tube, thus reducing mishandling or mislabelling and crosscontamination problems. A single paper smear is sufficient for as many as 10-12 PCR assays. This method offers a unique opportunity that a fraction of a cervical specimen can be employed as a paper smear and the rest could be processed for cytological Pap test or histopathology and the results can be compared with molecular diagnosis.

Dry storage of biological specimens on filter-paper at room temperature permits protection of DNA from degradation for a long period. In this study, dry smears were stored at room temperature for up to 1 year, with no alteration in the quality of DNA or subsequent PCR amplification (Fig. 3). The paper slides may be pretreated with antibiotics and fungicides or denaturants to prevent growth of bacteria and other micro-organisms. This method can be universally employed for almost all types of biological specimens, such as cultured cells, cervical and buccal smears, blood, urine, amniotic/ ascitic fluid, semen and bone marrow or needle aspirates, including solid tissue biopsy imprints.

Cervical scrapes and biopsies are often contaminated with blood and mucus, which might pose a potential problem for direct PCR. Erythrocyte contamination in cervical scrapes, particularly the porphyrin moiety of haemoglobin, acts as a strong inhibitor of PCR amplification [27]. Microwave treatment is capable of denaturing such inhibitory factors [28]; therefore, microwave treatment was used as an essential step before PCR amplification. Microwave treatment has also been shown to be efficient for elution of DNA from filter-paper blood spots [16] and to increase the sensitivity of PCR detection by about 2-3-fold [28]. Thus this method, which is a simple alternative to complicated conventional methods of collection, transport and storage of biological specimens, may be applied to population screening for a host of pathogens and genes, including for forensic purposes. The method is being used routinely in this laboratory for diagnostic and screening purposes.

\section{References}

1. Luthra UK, Prabhakar AK, Seth $\mathrm{P}$ et al. Natural history of precancerous and early cancerous lesions of the uterine cervix. Acta Cytol 1987; 31: 226-234.

2. Das BC, Gopalkrishna V, Hedau S, Katiyar S. Cancer of the uterine cervix and human papillomavirus infection. Current Science 2000; 78: 52-63.

3. World Health Organization. Control of cancer of cervix uteri. A WHO Meeting. Bull World Health Organ 1986; 64: $607-618$.
4. Howley PM. Role of the human papillomaviruses in human cancer. Cancer Res 1991; 51: 5019s-5022s.

5. zur Hausen H. Viruses in human cancers. Science 1991; 254: $1167-1173$.

6. zur Hausen H. Papillomavirus infections - a main cause of human cancers. Biochem Biophys Acta 1996; 1288: F55-F78.

7. de Villiers EM. Heterogenicity of the human papillomavirus group. J Virol 1989; 63: 4898-4903.

8. zur Hausen H. Papillomavirus as carcinoma viruses. Adv Virol Oncol 1989; 8: 1-26.

9. Das BC, Sharma JK, Gopalkrishna V et al. A high frequency of human papillomavirus DNA sequences in cervical carcinomas of Indian women as revealed by southern blot hybridization and polymerase chain reaction. J Med Virol 1992; 36: 239-245.

10. Das BC, Murthy NS, Sharma JK et al. Human papillomavirus and cervical cancer in Indian women. Lancet 1989; 2: 1271.

11. Cuzick J, Terry G, Ho L, Hollingworth T, Anderson M. Human papillomavirus type 16 DNA in cervical smears as predictor of high-grade cervical cancer. Lancet 1992; 339: 959-960.

12. Das BC, Sharma JK, Gopalkrishna V, Luthra UK. Analysis by polymerase chain reaction of the physical state of human papillomavirus type 16 DNA in cervical preneoplastic and neoplastic lesions. J Gen Virol 1992; 73: 2327-2336.

13. Lie AK, Isaksen CV, Skarsvag S, Haugen OA. Human papillomavirus (HPV) in high-grade cervical intraepithelial neoplasia (CIN) detected by morphology and polymerase chain reaction (PCR): a cytologic correlation of 277 cases treated with laser conization. Cytopathology 1998; 10: 112-121.

14. Paavonen J, Koutsky LA, Kaviat N. Cervical neoplasia and other STD-related genital and anal neoplasia. In: Holms KK, Mardh PA, Sperling PF, Weisner PJ (eds) New York, McGraw Hill. Sexually transmitted diseases, 2nd edn. 1990: 561-592.

15. Panteleeff DD, John G, Nduati R et al. Rapid method for screening dried blood samples on filter paper for human immunodeficiency virus type 1 DNA. J Clin Microbiol 1999; 37: $350-353$.

16. Gupta BP, Jayasuryan N, Jameel S. Direct detection of hepatitis $\mathrm{B}$ virus from dried blood spots by polymerase chain reaction amplification. J Clin Microbiol 1992; 30: 1913-1916.

17. Kain KC, Lanar DE. Determination of genetic variation within Plasmodium falciparum by using enzymatically amplified DNA from filter paper disks impregnated with whole blood. $J$ Clin Microbiol 1991; 29: 1171-1174.

18. Cassol S, Salas T, Arella M, Neumann P, Schechter MT, O'Shaughnessy M. Use of dried blood spot specimens in the detection of human immunodeficiency virus type 1 by the polymerase chain reaction. J Clin Microbiol 1991; 29: $667-671$.

19. Beebe JL, Briggs LC. Evaluation of enzyme-linked immunoassay systems for detection of human immunodeficiency virus type 1 antibody from filter paper disks impregnated with whole blood. J Clin Microbiol 1990; 28: 808-810.

20. Garrick MD, Dembure BS, Guthrie R. Sickle-cell anemia and other hemoglobinopathies: procedures and strategy from screening employing spots of blood on filter paper as specimens. N Engl J Med 1973; 288: 1265-1268.

21. Bickel HC, Bachman C, Beacker R. Neonatal mass screening for metabolic disorders. Eur J Pediatr 1981; 137: $133-139$.

22. Maeda M, Ito K, Arakawa H, Tsuija A. An enzyme-linked immunosorbent assay for thyroxine in dried blood spotted on filter paper. J Immunol Methods 1985; 82: 83-89.

23. Gopalkrishna V, Francis A, Sharma JK, Das BC. A simple and rapid method of high quality DNA isolation from cervical scrapes for detection of human papillomavirus infection. $J$ Virol Methods 1992; 36: 63-72.

24. Sambrook J, Fritsch EF, Maniatis T. Molecular cloning. A laboratory manual, 2nd edn. Cold Spring Harbor, NY, Cold Spring Harbor Laboratory Press. 1989.

25. Kwok S, Higuchi R. Avoiding false positives with PCR. Nature 1989; 339: 237-238.

26. Jeanpierre M. A rapid method for the purification of DNA from blood. Nucleic Acids Res 1987; 15: 9611.

27. Higuchi R. Rapid, efficient DNA extraction for PCR from cells or blood. Amplifications 1989; 2: 1-3.

28. Cheryrou A, Guymarch'h C, Jasserand P, Blouin P. Improved detection of HBV DNA by PCR after microwave treatment of serum. Nucleic Acids Res 1991; 19: 4006. 